\title{
Samaun Bakri: Nationalist Portrait in 1925-1948
}

\author{
Abdul Salam \\ Department of History Education, Padang State University \\ abdulsalam.unp@gmail.com
}

\begin{tabular}{ccc}
\hline Received & Accepted & Published \\
$17 / 03 / 2018$ & $27 / 04 / 2018$ & $30 / 04 / 2018$ \\
\hline
\end{tabular}

Abstract Samaun Bakri is one of many figures from Nagari Kurai Taji Pariaman West Sumatra, which enliven the national political stage. His movement in the Dutch Colonial period, began when he attended in Sumatra Thawalib Padang Panjang. The Kuminih movement, fronted by Communist propagandists, has changed its paradigm of thinking from moderate to radical. Sometimes Samaun is often the target of arrest with allegations of infidelity. This paper is compiled based on historical method, consist of; heuristics, criticism, interpretation, and historiography. The world of Islamic movement and modernization has indeed influenced the way of Samaun thinking. Several times, he was involved in the press, ranging from Persamaan, Sasaran, Penabur, and often wrote harsh criticisms of the Dutch government. After the Silungkang incident, he crossed over to the Partai Nasional Indonesia (PNI). During the Japanese occupation, he was involved in the management of PUTERA and Jawa Hokokai. His political career post-independence immediately dashed, when he served as Deputy Governor of West Java in 1946, KNIP members represent West Java, and became Deputy Resident of Banten in 1946-1948.

Keywords: biography; Samaun; movement; press; radical.

\begin{abstract}
Abstrak Samaun Bakri adalah salah satu tokoh dari Nagari Kurai Taji Pariaman Sumatera Barat, yang memeriahkan panggung politik nasional. Pergerakannya di masa Kolonial Belanda, dimulai ketika ia hadir di Sumatera Thawalib Padang Panjang. Gerakan Kuminih, yang digawangi oleh propagandis Komunis, telah mengubah paradigma berpikirnya dari moderat menjadi radikal. Terkadang Samaun sering menjadi target penangkapan dengan tuduhan perselingkuhan. Makalah ini disusun berdasarkan metode historis, terdiri dari; heuristik, kritik, interpretasi, dan historiografi. Dunia gerakan Islam dan modernisasi memang mempengaruhi cara berpikir Samaun. Beberapa kali, ia terlibat dalam pers, mulai dari Persamaan, Sasaran, Penabur, dan sering menulis kritik keras terhadap pemerintah Belanda. Setelah insiden Silungkang, ia menyeberang ke Partai Nasional Indonesia (PNI). Selama pendudukan Jepang, ia terlibat dalam pengelolaan PUTERA dan Jawa Hokokai. Karier politiknya pasca-kemerdekaan segera pupus, ketika ia menjabat sebagai Wakil Gubernur Jawa Barat pada tahun 1946, anggota KNIP mewakili Jawa Barat, dan menjadi Wakil Residen Banten pada 1946-1948.
\end{abstract}

Kata kunci: biografi; Samaun; gerakan; pers; radikal. 


\section{INTRODUCTION}

Every moment of Independence is commemorated, all eyes will be upon the preaching of the preparation of the text of the Proclamation on the morning of August 17, 1945 at the house of Laksamana Tadashi Maeda. Everyone must know a list of names, the start of Soekarno, Hatta, Ahmad Soebardjo, Chaerul Saleh, BM. Diah, Sayuti Melik, and Soediro, but of course rarely know the figure of Samaun Bakri (Malik, 1950 \& Anwar, 1948). Samaun Bakri, a son born in Nagari Kurai Taji Pariaman West Sumatra, is indeed included in the sheet of national history. His name again echoed in Kompas news, when Peltu Ilyas rediscovered the debris from the DC3 RI 002 aircraft on April 14, 1978 around Lampung. He has previously been awarded the title of Independence Pioneer from the Republic of Indonesia (UU No. 5 Prps-1964 and Minister of Social Affairs Decree No. Pol 7I/19.31/PK/Jd).

Samaun Bakri is a radical youth who is active in the world of movement, even though he attended school in Sumatra Thawalib Padang Panjang. The impact of Kuminih infected by Haji Ahmad Khatib Datuk Batuah cs in the period of 1923, influenced Samaun's attitude and paradigm of thinking that initially moderate to be radical (Sufyan, 2017). The changes in orientation and ideology choice of Samaun, of course, can happen. Padang Panjang called Audrey Kahin as the area that became the connecting gateway between the west coast of Sumatra and Minangkabau inland, has been transformed as the basis of education and modernization of Islam (Kahin, 1996). Since 1925-1928, Samaun has coordinated a radical movement, especially among the youth in Pariaman. Her passion in the world of correspondence has brought Samaun in journalistic activities. Noted during his stay in Pariaman, he was once the correspondent of the Persamaan newspaper. Through his writings, he often criticizes the Dutch colonial government's policies that mislead the people. The impact, Samaun became the target of the Dutch government's arrest because it was considered to have destroyed the order of rust en orde.

In 1935 Samaun chose to leave his village and move to Medan and then to Bengkulu. Apparently, he never deterred from his activities that were considered hostile to the Dutch government. In Bengkulu, Samaun is back in the world of movement. This time he actively takes care of Muhammadiyah Bengkulu Region and Partai Serikat Islam Indonesia (PSII) Bengkulu. Samaun was active again in journalism, he headed the newsletter of Penabur and Sasaran. Again he strongly criticized the Dutch colonial government policy, especially in the field of health. Samaun criticized the head of Bengkulu Hospital who often insulted indigenous people who treated with inlander designation. The impact, Semaun was subjected to exorbitant rechten and spent two years in prison.

The entering the Japanese occupation, there was a change of orientation in the world of Samaun movement. if he had been radical to Dutch colonial government policy, the Japanese 
period he chose moderation. Samaun is involved in the two largest organizations of the Japanese period, namely in PUTERA and Jawa Hokokai. His political career peaked after independence. His proximity with Soekarno and Hatta, his activities from Dutch Colonial to Japanese made him "dumped " into the government stage. Since elected as a member of KNIP, in the period 1946-1948 Samaun once occupied the position of Vice Resident of West Java and Banten. This is the interesting side of the political activities of Samaun Bakri, so the author is interested in studying this topic with the title "Samaun Bakri: Nationalist Portrait in 19251948."

\section{METHOD}

To develop this research, the authors put forward two items of the question, how the portrait of the life of Samaun Bakri ?, and what factors affect the activities of Samaun in the stage of politics and government? All questions asked above will be answered in the discussion. This paper is compiled based on historical method, the consist of heuristic, critic, interpretation, and historiography.

The writings that reveal Samaun Bakri's identity and activities, from the literature of the book, article, thesis and dissertations are few to mention. Adam Malik (1950) in Riwayat Proklamasi Agustus 1945 that published by Widjaja there is indeed mention of Samaun, but only one line. Malik recounts the role of some members of the text preparation of Proclamation and one of them is Samaun Bakri. Fuad Bakri and Teguh Wiyono (2014) in Samaun Bakri. Sang Jurnalis dan Misteri Jatuhnya RI 002 more recounts about Samaun Bakri. However, this biography still leaves a lot of important things about the figure as former Deputy Resident of Banten period 1946-1948. In addition, Samaun Bakri's biography was written, without the use of years, places, and etc. From the two previous studies known, there have been some who wrote the biography of Samaun Bakri, but who alluded to his movement during the years 19251948, no one has discussed.

The study of Samaun Bakri is closely related to the concept of biography. Why is biography always interesting to talk about? Biography can be defined as writing a person's life history (Sagimund, 1993). Taufik Abdullah (1983) suggests a biography is a form of historical writing that seeks to reveal the activities of a person, within the context of a certain time, without ignoring the relationship between the character with the development of the times and the environment.

Sartono Kartodirdjo (1993) also reveals the biography as a unit of history that since classical times has been written by the historiographical of Taetus, to strengthen an actor, biography becomes the main tool. That is, biography is not a new product in historiography, but a series of stories that began in Ancient Greek era. Well-written biographies, both by academic 
and amateur historians, are expected to inspire readers. Understanding and deepening the personality of a person is demanded the background knowledge of the socio-cultural environment in which the character is born, how the process of formal and informal education undertaken, the characters around him.

Samaun Bakri's biography is essentially related to thematic biographical studies, where this study has some similarities to the mentality history. The mentality history involves not only ideas or thoughts that affect a particular historical process but also a structure of consciousness, which is also present in the mentality of human and society. This means that the life biography of Samaun Bakri cannot be separated from the birthplace, cultural environment, education, soul of the times (zeitgeist) that affect the life of this character.

\section{RESULT RESEARCH AND DISCUSSION}

\section{About Samaun Bakri}

Samaun Bakri was born on April 28, 1908 in Nagari Kurai Taji of the couple Bagindo Abu Bakar and Siti Syarifah. Kurai Taji in its history sheet is known as one of the areas that have links with other regions in Pariaman. In $M v O 1910$ called the name "Kuraitaji" in the lyrics, Salareh Sunua-Kuraitaji, Pauah Kamba jo Bintuang Tinggi. In oral tradition study, Kurai Taji's name begins with the story of a chicken bout by Kuraiese origin who gave a spur on the chicken feet of his complaint.

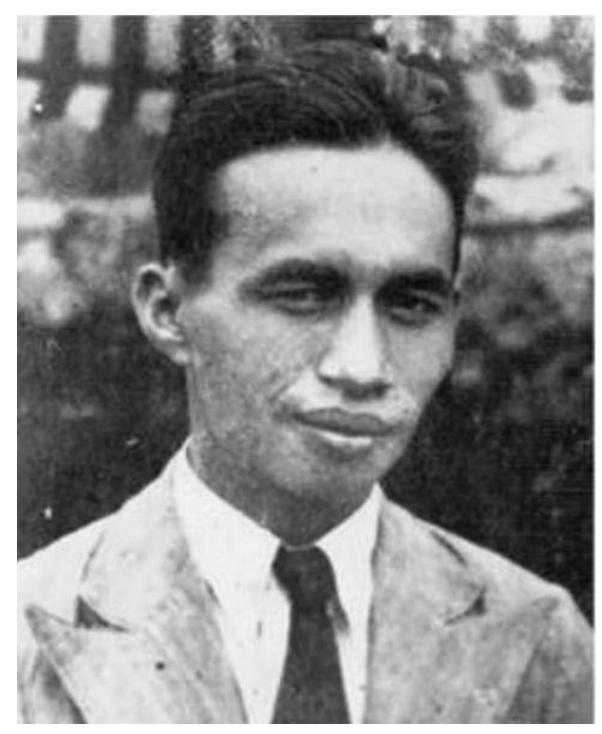

Picture 1. Samaun Bakri (1908-1948) son of birth form Nagari Kurai Taji Pariaman That active in the movement world in West Sumatera and Bengkulu. Source: In the reproduction of Singgalang January 11, 2015.

Samaun was born, when the national movement carries the ethical-political spirit of Theodore van Deventer and the development of Islamic modernization centred in Padang Panjang, Bukittinggi, and Padang. Uniquely, Kurai Taji at that time was still influenced by the teachings of the Syattariyah centred in Ulakan. When entering the age of study, both parents argue Samaun, to which school will be included. Bagindo Abu Bakar wants his son to go to 
Pariaman Schkakel School, while his mother wants Samaun to enter the surau education led by Sultan Rajo Alif (Bakri \& Wiyono, 2014). It is not known exactly when Samaun entered school, he completed his studies in 1920.

After in Schkakel School, his parent still debating where Samaun continued his education. Seeing the quarrel, he went on to become parewa and often enliven indang events and laua ambek (a kind of martial arts from Pariaman). Seeing the bad signs to his son, Syarifah sent his son to Padang Panjang. Samaun was schooled at Thawalib School in 1922.

The reason for choosing Sumatra Thawalib certainly makes sense. Syarifah wants her son to become a great mufti in Kurai Taji. In addition to the wisdom of the modernist Islamic school pioneered by Haji Abdul Karim Amrullah, it has been well known in Minangkabau, with the characteristic of his tafsir studies. A year of schooling, Thawalib School hit by Kuminih impact propagandist duo propagandist Haji Ahmad Khatib title Datuk Batuah and Natar Zainuddin - a crossbreed Padang and India.

In some literature does not mention the involvement of Samaun in the left movement. When connected later with changes in attitude that previously tended to be submissive and reserved, to be radical and like to protest, most likely Samaun dissolve in the left movement in International Debating Club or in Bufet Merah (name of the canteen in Sumatera). Burhanuddin Daya in his writing, mentions that generally students in Thawalib School that time was interested in radical ideology offered by the auxiliary teacher as well as an editorial assistant of Al-Munir Al-Manar magazine (Daya, 1990).

The widespread impact of communism in Thawalib School, causing Syarifah to be anxious. She does not want his son to enter into practical politics. Samaun was withdrawn back to his hometown in 1925. Bagindo Abu Bakar then brought Samaun to Padang for school and took a foreign language course. A year of study in Padang, in 1926 Samaun Bakri had worked in the West Sumatra Resident Office. He only worked a few months, then choose to go home, because it is not strong with the treatment of Dutch officials who seemed to underestimate his personal, as inlander (Bakri \& Wiyono, 2014).

After working in Padang, Samaun Bakri dissolves in the movement organization. At the age of 19, Samaun was already a member of PNI (1927). The spirit of actively mobilized nationalism within the PNI has prompted it to rebel against the policies of the Dutch East Indies government. He also shouted loudly, while riding a steam train to Pariaman, " The train we have, the highway we have, Ombilin we have!". Not only asking, Samaun also proved in the act, that when he joined in a rebellion, then quickly prevented by the Dutch East Indies troops.

Samaun was involved in the uprising in Pariaman and Padang Panjang at that time. so the Dutch colonial government was arrested in Lubuk Alung, but released as 19 years old. Two years later, the influence of modernization of Islam began to enter Kurai Taji with the founding 
of the Muhammadiyah branch of Kuraitaji in 1929 (Munafi, 1985). The rise of the Islamic modernist organization, prompting Samaun Bakri to end his adventures in radical movements and join to develop Islamic reformism. Together with Oedin (after independence was appointed as Regent of Rengat), Haji Haroen el-Maany (teacher in KMM (Kulliyyatul Muballighin Muhammadiyah) Padang Panjang and Chairman of the Regional Leadership in Muhammadiyah West Sumatra 1966-1967), Sidi M. Ilyas, M. Luthan, Sulaiman Munaf (director of Madrasah Tsanawiyah Kurai Taji 1940-1942), Kasim Munafy, he is a big role in developing Muhammadiyah group Kurai Taji.

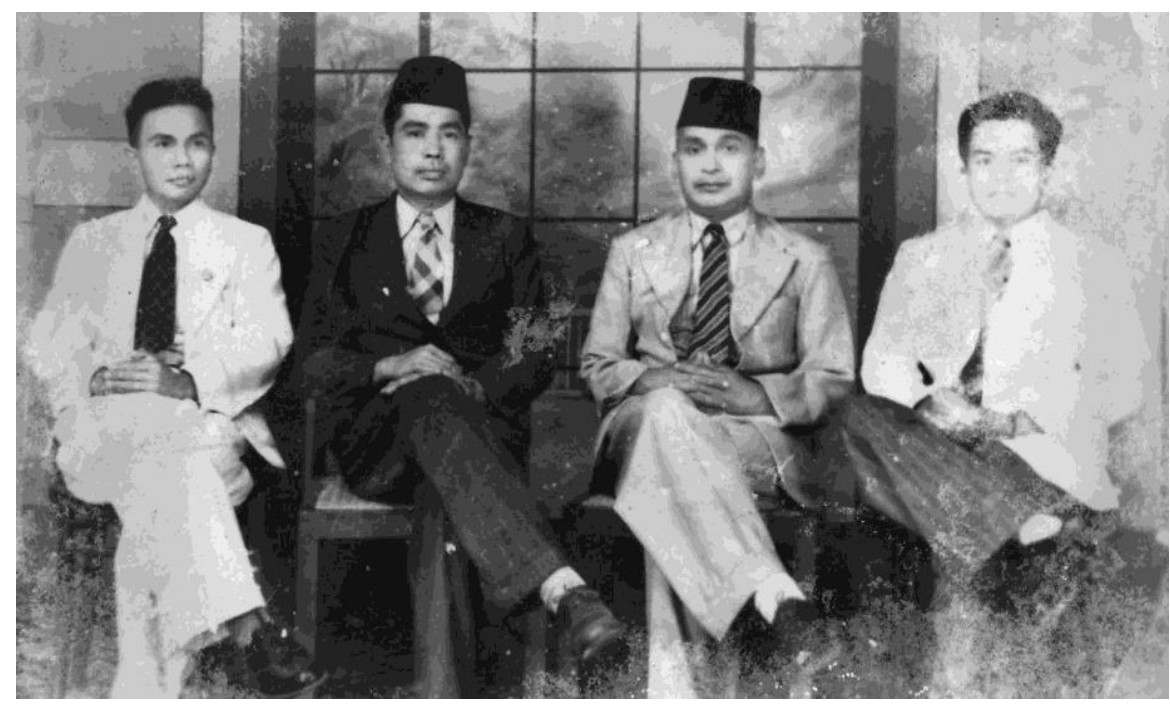

Gambar 2. The founders of Muhammadiyah Groep Kurai Taji no.2 and no.3 that is Sidi M. Ilyas and Oedin. The leftmost is Kasim Munafy and right is Syailendra. Source: In the reproduction of the documentation of Kasim Munafy.

In addition to active in Muhammadiyah, Samaun has worked as a "kuli tinta" in the Harian Persamaan. Apparently, the radical soul and its critical nature of the Dutch East Indies government never disappeared. One of the officials he often criticized was a controller named Spit. Unlike the character of society at that time who tend to choose safe, Samaun even too daring to criticize, which he put forward in the Persamaan newspaper. Of course, Spit is hurt. He also used the services of Kurai Taji Chief Chairman, Moh. Noer Majolelo to drive Samaun Bakri out of his hometown( Bakri \& Wiyono, 2014).

\section{Moved to Bengkulu and Changed the Movement at the Dai Nippon Era}

The household story is winding. Recorded in its history, Samaun Bakri married three women. Married to a Sunur girl named Zubaidah in 1928 was blessed with a son named Abdul Muis, married Siti Hafsah and had a son named Siti Asma, and married a student at Khadijah School named Siti Maryam in 1936 and was blessed with a son named Fuad S. Bakri (Minister of Social Affairs Decree No.Pol 7I/19.31/PK/Jd.). 
The heavy pressure from the Dutch East Indies government, especially after the economic crisis of the 1930s, forced Samaun to leave the world of movement. He chose to wander outside West Sumatra. The selected overseas was the area of Bengkulu which was also the migration area of Minangkabau society long before the arrival of Europeans.

In 1938, Samaun returned to his profession as a journalist of the Sasaran in Bengkulu. However, this newspaper did not last long, because the style of writing Samaun often attack the policies of the Dutch colonial government at that time, causing the Sasaran is prohibited by the Dutch East Indies government. The allegations against the press in violation of the code of ethics or persdelict actually have been going on since 1919. In September 1919, Limburg Stirum issued a circular muilkorf-circulaire (prohibition letter) to speech, deeds, and writings that disturb the authority of the government. The release of this circular, enabling government representatives in each region to take legal action and prosecute persons or institutions that threaten the stability of the Netherlands Indies. Some of the government's arrest action, among others, arrested Haji Misbach in 1919, on suspicion of incitement in Surakarta, detained Tjipto Mangunkusumo and Douwes Dekker on allegations of persdelict. According to the Europeans of the time, the act of capturing the movement figures has not guaranteed that the actions of radicalism could be reduced. However, the appointment of the Secretary of State De Graff in November 1919, gave birth to a more conservative policy, so sympathy for nationalism and communism tends to decline.

After the closing of this newspaper, Samaun Bakri began preparing a more moderate Penabur newspaper, compared to a Sasaran newspaper that had been banned by the Dutch government. The presence of Samaun in Bengkulu also influenced his career on the stage of politics and government. Since living in Bengkulu, Samaun has been actively involved in the PSII and Muhammadiyah of Bengkulu Region. Here, he is familiar with the chairman of Muhammadiyah Bengkulu named Hasan Dinayah- father of Fatmawati, later made wife by Bung Karno.

Starting from his proximity to Hasan, plus he was allowed to teach at one of the Muhammadiyah schools, where one of the students he taught was Fatmawati when it started also Samaun's closeness with Bung Karno. The role of Samaun Bakri takes care of the marriage plans of Bung Karno and Fatmawati, once written completely in the writings of Cindy Adams in 1966. 


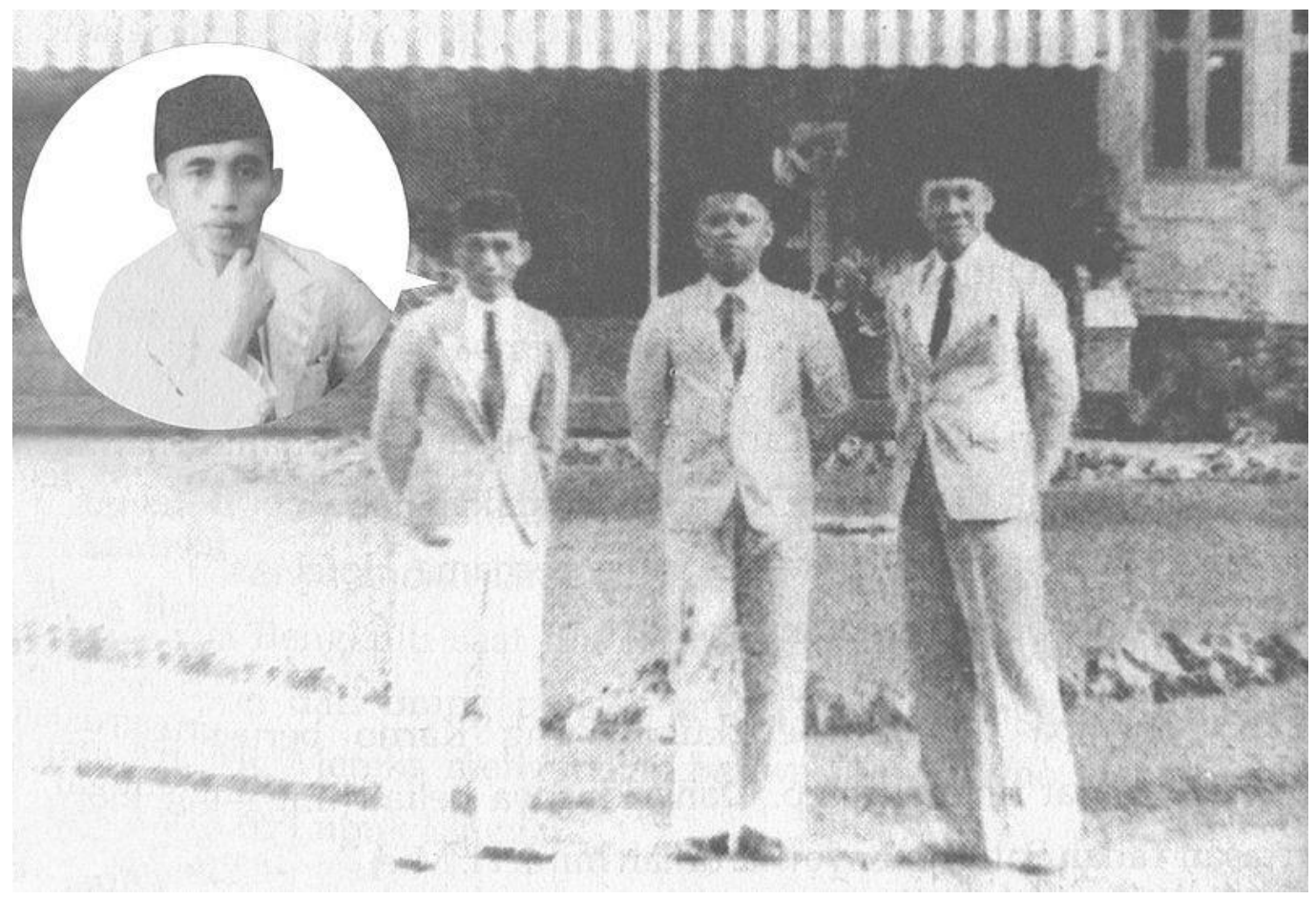

Gambar 3. Samaun Bakry (most left) with Bung Karno (right) in front of his home in Bengkulu in 1939.

Source: In reproduction by Bakry and Wiyono, 2015.

Since meeting with Bung Karno, Samaun learned a lot from his student HOS Tjokroaminoto. He learned about political strategy, when faced with Dutch colonial rule, in addition to Samaun will later become a confidant of Bung Karno during his stay in Bengkulu.

\section{The career in Government and the Last Life of Samaun Bakri}

When Japan entered and occupied Indonesia, Samaun became assistant to K.H. Mas Mansoer, who was with Sukarno, Mohammad Hatta, and Ki Hajar Dewantara (Empat Serangkai) led a Japanese-formed organization called PUTERA (Pusat Tenaga Rakyat). The PUTERA is an organization established by the Japanese government on April 16, 1943 and headed by Soekarno, Moh. Hatta, Ki Hajar Dewantoro and K.H Mas Mansyur (Jong, 1987). The aims of PUTERA is to persuade Nationalists and intellectuals to devote their minds and energies to the war against the Allies and to be hoped that with the leader of the Indonesian people the people will fully support this goal. In a short time, PUTERA can expand to areas with members is a collection of professional organizations such as Perkumpulan Guru Indonesia, Perkumpulan Pegawai Pos, Radio and Telegraph, Perkumpulan Istri Indonesia, Barisan Banteng, Badan Perantara Pelajar Indonesia, and Ikatan Sport Indonesia.

The existence of PUTERA is an official government organization distributed through newspapers and radio, reaching out to the village, but not getting operational funding. Despite the limited activity, the PUTERA leaders utilized the mass media provided to follow and observe 
the outside world situation and communicate with the people. In the bustle of Samaun being the administrator of PUTERA, Samaun was sent by Soekarno to bring messages and gifts to Fatmawati in Bengkulu. He was with Abdul Karim Oei and dr. Moh. Djamil then also took care of marriage Fatmawati with Soekarno on June 1, 1943, which represented his close friend, overseer (supervisor) Sarjono. After the marriage, Samaun then took and escorted Fatmawati and his entourage consisting of Fatmawati's parents and uncle, Moh. Kancil, who also tailors Bung Karno's clothes while in Bengkulu to Jakarta. During the activity at PUTERA, Samaun remains a trusted person of Bung Karno.

Because unfavourable for Japan, PUTERA only lasted for a year, then dissolved and replaced with Jawa Hokokai (Oktorino, 2016). And in this organization, back to Samaun involved in membership. Samaun's role continued as he was one of the witnesses in the preparation of the Proclamation text at the house of Laksamana Maeda. In his writings, Adam Malik clearly wrote the involvement of Samaun in the process of preparing the text of the Proclamation, which will be signed by Bung Karno and Bung Hatta.

"Witnessed by Sukarni, Chairul Saleh, Mr. Subarjo, Mr. Iwa Kusumasumantri, Sudiro (Mbah), B.M. Diah, Sayuti Melik, Samaun Bakri, around two o'clock in the morning on August 17, 1945, signed the text of the Proclamation by Bung Karno and Hatta on behalf of the Indonesian People.." (Malik, 1950). Subsequently, on August 18, 1945, Samaun Bakri was appointed as one of the members of BP Komite Nasional Indonesia Pusat (KNIP) and KNIP West Java. In addition to serving as a member of KNIP, Samaun is also appointed as Secretary of West Java Governor. His appointment coincided with the Bandung Lautan Api on March 24, 1946. At that time, he was with Chairul Saleh and several other military figures fighting against the Dutch onslaught in Bandung. As one of history's witnesses, Samaun wrote his memories in Setahoen Peristiwa Bandoeng.

The bureaucracy career of Samaun Bakri increasing as the revolution began to subside in Banten in December 1946. Samaun at that time was inaugurated as Vice Resident of Banten accompanied KH. Ahmad Khatib. To help the government-run almost under the control of the mufti, the government appoints civilian and military officers. However, unfortunately, in this incident, Samaun did not leave a note of importance during being a Vice-Resident and no further explanation from the author concerning his activity.

Samaun started actively in the political party that is in Masyumi. He began to follow Masyumi when the Priangan Masyumi conference was held in 1946. Samaun at that time was appointed as head of Information and Broadcasting. In addition to Samaun, also appointed AA Achsin (Chairman of the Treasury), Ali Ratman (Treasurer), Zainuddin (Chairman of Social Economics), Roesjad (Chairman of the Youth Council), and others. 
The story of Samaun Bakri's life ended with the tragic accident of Dakota 02 plane in Palembang (Singgalang, 2014). or thirty years, Samaun Bakri's extended family awaited the clarity of his fate, on April 6, 1978, the wreck of a plane newly discovered (Padang Ekspres, 2014). The victims in the wreckage beside Samaun Bakri are Robert Freeberg (pilot), Bambang Saptoadji (co-pilot), Sumadi (engineering expert), Suryatman (radio operator), and Santoso (copilot two). The body of Samaun Bakri was buried in the hero grave of Kedaton Lampung (Letter No.13/136-20/7/15/TAL).

\section{CONCLUSION}

Samaun Bakri in his movement shows a person who tends to be consistent in his movements, indeed tends to vis a vis the Dutch Colonial government. The magnitude of the influence and zeitgeist of Sumatra Thawalib which tended to be left in the 1920s did influence Samaun's attitude and behaviour.

The person who was initially quiet and submissive later turned into a protestor and radical, indeed he addressed to the Dutch East Indies government, which he often attacked through his writings in Persamaan, Sasaran, and Penabur.

In 1927, Semaun has changed ideology. He became a nationalist, but loyal to the ideas of Islamic modernization which he then participated in Muhammadiyah Groep in Kurai Taji and Muhammadiyah in Bengkulu Region. From emotional closeness with Bung Karno, as well as a marker of his political career improvement, he is clearly a Sukarnois, can also embrace the ideology of Marhaenism. The proximity of this ideology also made Samaun switch to the government stage, one of them as the Vice-Resident of Banten.

\section{REFERENCES}

Abdullah, T. (1983). Manusia dalam Kemelut Sejarah. Jakarta: LP3ES.

Adams, C. (1966). Bung Karno. Penyambung Lidah Rakyat Indonesia. Jakarta: Gunung Agung.

Anwar, R. (1948). Kisah-kisah Jakarta Setelah Proklamasi. Jakarta: Pustaka Jaya.

Bakri, F.S \& Wiyono, T. (2014). Samaun Bakri. Sang Jurnalis dan Misteri Jatuhnya RI 002. Jakarta: Rajawali Konsultan.

Daya, B. (1990). Gerakan Pembaharuan Pemikiran Islam. Kasus Sumatra Thawalib. Yogyakarta: Tiara Wacana.

Jong, L.D. (1987). Pendudukan Jepang di Indonesia. Jakarta: Gramedia.

Kahin, A. (1996). “The 1927 Communist Uprising in Sumatra: A Reap-raissal”, Jurnal Indonesia Vol. 62. 
Kartodirdjo, S. (1993). Pendekatan Ilmu Sosial dalam Metodologi Sejarah. Jakarta: Gramedia.

Kompas tanggal 2 Juni 1981, 3 Juni 1981, dan 29 Juni 1981.

Letter No.13/136-20/7/15/TAL tentang pemakaman kerangka jenazah awak kapal dan penumpang pesawat RI 002 kepada Wakil Presiden Adam Malik.

Malik, A. (1950). Riwayat Proklamasi Agustus 1945. Jakarta: Widjaja.

Sagimund. (1993). Dalam Pemikiran Biografi dan Kesejarahan. Jakarta: Gramedia.

Minister of Social Affairs Decree No.Pol 7I/19.31/PK/Jd

Munafi, K. (1985). "Muhammadiyah yang Aku Kenal", Manuskrip. Sejarah Kehidupan Pribadiku: Kasim Munafi.

Oktorino, N. (2016). Dibawah Matahari Terbit. Sejarah Pendudukan Jepang di Indonesia. Jakarta: Elex Media Komputindo.

Padang Ekspres, 4 September 2014.

Singgalang, 1 September 2014, 11 Januari 2015.

Sufyan, F.H. (2017). Menuju Lentera Merah. Gerakan Propagandis Komunis 1923-1949 di Serambi Mekah. Yogyakarta: UGM Press.

UU No. 5 Prps-1964. 